\title{
MARCAS DA MUTAÇÃO: VIOLÊNCIA E IDENTIDADE NO CINEMA DE CRONENBERG
}




\title{
MARCAS DA MUTAÇÃO: VIOLÊNCIA E IDENTIDADE NO CINEMA DE CRONENBERG
}

Resumo:

O cinema de David Cronenberg possui vasta afinidade com processo que caracterizam o que poderíamos entender por "espírito pós-moderno". Trata-se de um diretor que busca adentrar os meandros da alma humana. Neste artigo buscamos abordar as relações entre a obra de Cronenberg e a questão angustiante da identidade, tão afeita ao debate em campos como a comunicação, antropologia e psicologia.

Palavras chave: David Cronenberg; Violência; Identidade; Comunicação; Cinema

\section{MARCAS DE LA MUTACIÓN: LA VIOLENCIA Y LA IDENTIDAD EN EL CINE DE DAVID CRONENBERG}

Resúmen:

El cine de David Cronenberg cuenta con un proceso amplio de afinidad que caracteriza a lo que entendemos "espíritu posmoderno". És un director que busca entrar en las complejidades del alma humana. En este artículo se pretende abordar la questión angustiosa de la identidad, tan acostumbrada a debate en campos como la comunicación, la antropologia y la psicologia.

Palabras clave: David Cronenberg; Violencia; Identidad; Comunicación; Cine

\section{BRANDS OF MUTATION: VIOLENCE AND IDENTITY IN THE CINEMA OF DAVID CRONENBERG}

\begin{abstract}
:
The cinema of David Cronenberg has extensive affinity with the process that characterize what we could understand "postmodern spirit". Cronenberg is a director who seeks to enter in the meanders of the human soul. In this article we seek to address the relationship between the work of Cronenberg and the distressful question of identity, so typical to debate in fields like communication, anthropology and psychology.
\end{abstract}

Keywords: David Cronenberg; Violence; Identity; Communication; Cinema 


\title{
1 UMA IDENTIDADE CRONENBERGUIANA Á GUISA DE INTRODUÇÃO
}

\author{
Perdi-me dentro de mim \\ Porque eu era labirinto, \\ E hoje, quando me sinto, \\ É com saudades de mim. \\ Sá-Carneiro
}

Não é incomum encontramos, em meio a leituras e pesquisas acerca do fenômeno entendido por pós-modernidade, bem como na literatura de pensadores sobre os problemas identitários comum a este processo, o nome de David Cronenberg. Cineasta canadense, já aparecia como curiosidade em filmes realizados na década de 1970, como Enraivecida na fúria do sexo ou Filhos do medo, até obter repercussão global com Scanners - sua mente pode destruir'1. Notável pelos efeitos especiais, pelo gosto e afinidade com o insólito, com as afiliações com formas perturbadas, mutacionais, com figuras monstruosas e processos massacrantes, seu nome foi se configurando em objeto de culto por parte de admiradores do cinema e de estudo e intriga por pensadores de processos característicos de nosso tempo. Jean Baudrillard se referiu a ele em diversas ocasiões, bem como outros autores.

Cronenberg, afeito a trabalhos de ficção, com frequência salienta em suas obras sua tendência para a reflexão acerca de processos importantes na modernidade ou na pós-modernidade, frequentemente trazendo em si algumas angústias como a relação do homem com a tecnologia, conforme observamos em Videodrome ou Crash - Estranhos prazeres. Se pensarmos na antiga reflexão sobre o chamado cinema de autor ${ }^{2}$, uma questão logo se apresentaria como crucial: seria Cronenberg um cineasta autoral? Ou, adaptando ao destino do presente trabalho: qual seria a identidade de Cronenberg? Podemos notar, de antemão, certas tendências em seu cinema que fiariam curiosa unidade em sua obra. Seus personagens com frequência parecem "eus" à deriva, abandonados à própria sorte ou precisando resistir às tentações de um mundo opressivo. Assim, são pintados como almas cuja identidade não parece facilmente reconhecível ou, antes, possuem certo aspecto caro às figuras mutantes: identidades camaleônicas, voláteis, ora estáveis e tranquilas, ora aniquiladas e destrutivas. O universo de Cronenberg é um mosaico fascinante de criaturas em franco processo crítico. Criaturas que, em reação a um mundo que perde seu "chão", sentindo-se deslocadas e sem sentido - como veremos em M. Butterfly - passam ao esmolar por uma nesga de identidade³. Assim, impressiona-os

1Ver ao final relação de filme do cineasta, com mais informações.

2A questão do cinema de autor é associada, com frequência, ao nome dos críticos franceses da revista Cahiérs du cinema nos anos de 1950, reunidos em torno da figura de André Bazin. Em linhas gerais, entende que o cineasta deve possuir um registro próprio, uma característica que possa identificá-lo como "autoral", seja Hitchcock, Buñuel, Antonioni, Dreyer etc. Uma noção que valoriza a liberdade do diretor em detrimento às amarras das produtoras.

3Spider, de 2002, é um ótimo exemplo, trazendo o ator Ralph Fiennes na pele de um esquizofrênico de meia idade, oscilando entre seu presente confuso e sua infância traumática. 
acima de tudo o caráter - cruel, talvez - de degradação, mutilação e solidão no espaço cronenberguiano. Um cineasta que ora recorre ao monstro e à anomalia como expressão estética de seres perdidos; ora, abdica do horror na imagem a fim de recriá-lo psicologicamente, pretendendo não apenas mostrar as crises de identidade no âmbito da ficção científica (A mosca, como veremos, ou Naked lunch), como também trazê-las em contextos dramáticos que poderíamos chamar de "plausíveis": Marcas da violência ou Senhores do crime. Nogueira (2002) coloca importante reflexão sobre o universo do cineasta:

Cineasta das mutações, das debilidades, das máscaras e das perturbações carnais, David Cronenberg é também, de forma singular, um exímio analista, filósofo e retratista das solidões e das volatilidades das almas, bem como dos fantasmas que acometem e das fantasias e anomalias onde se perdem e dilaceram. O seu trabalho desenvolve-se naquela linha onde essas duas instâncias da existência humana (corpo e mente) se enleiam, questionam e dissolvem, com todas as violências que advêm, pela doença e pela contaminação, aos seres em deriva. (NOGUEIRA, 2002, p. 57)

Pergunta-se o autor português: "que ganhos auferem esses seres, que perdas se suportam quando a vida é assumida como experiência radical, violência e enfrentamento?" ". Para este trabalho, limitamo-nos a meditar sobre três obras do cineasta canadiano, a fim de melhor delimitar os objetivos da abordagem: os processos identitários, suas gradações, suas angústias no universo de Cronenberg. Tais filmes são $M$. Butterfly, e conjuntamente $A$ mosca e Marcas da violência, em virtude de certas afinidades que serão mais bem explicadas no devido momento.

\section{SERES MUTACIONAIS E A SEDE POR IDENTIDADE: A MOSCA E MARCAS DA VIOLÊNCIA}

\subsection{A metamorfose do inseto dentro do homem}

O cientista Seth convida a jornalista Veronica5 (Ronnie) para conhecer sua máquina de teletransporte, ainda em fase experimental. Quase a contragosto, a moça aceita o convite e fica espantada ao ver que o experimento de Seth é um sucesso. Da máquina $A$, Seth consegue fazer seu babuíno de testes adentrar a máquina $\mathrm{B}$, num processo em que sua conjuntura biológica, orgânica, celular, é decomposta e recomposta com perfeição. O fascínio tomará conta de todos, mas logo o terror irá se instaurar. Ao refazer a experiência consigo mesmo, Seth realiza o transporte com a presença de uma mosca -

4Nogueira, 2002, p. 58

5 Vividos pelos atores Jeff Goldblum e Geena Davis. 
sem o perceber. Ao se "recompor", será ele agora um ser humano dotado de genes do inseto, bem como de suas características genéticas. De ser humano, Seth passa a uma espécie de "homem mosca", e pouco a pouco seu corpo vai passando por metamorfoses típicas do animal. No humano, desperta o bestial; o instinto sexual insaciável; a força física anormal, a capacidade de subir pelas paredes, seu paladar, seus pêlos, até por fim uma metamorfose completa. $O$ corpo humano se torna volátil, até chegar ao estado descartável, asqueroso.

Cronenberg, ao realizar A mosca, toca em vários aspectos comuns aos problemas contemporâneos, e que marcam insistentemente sua produção cinematográfica. A violência, o medo, a presença hospedeira e potencial de uma besta imanente no interior do homem - talvez uma metáfora para nossas potencialidades primitivas, ocultas, nosso "lado negro". Por conseguinte, outra identidade no cerne de si mesmo; embora use da alteração corpórea enquanto metáfora, o autor especula, sem dúvida, sobre as consequências dentro do homem: quais as mudanças que ocorrem no comportamento de Seth, antes "homem", agora um ser mutante?

Talvez, na obra de Cronenberg, nenhum outro filme demonstre melhor tais idéias - nossos "eus" imanentes, nossos "monstros hospedeiros", ou a possibilidade de a civilidade ceder lugar ao pleno animalesco, como no emergir daquilo que Melanie Klein chamava de "objetos terroríficos" como em A mosca, filme que, como veremos, parece possuir um curioso desdobramento, quase vinte anos depois, em Marcas da violência.

Após a monstruosidade genética que assola Seth, seus genes também se metamorfoseiam, e sua parceira, grávida, carregará consigo os genes dessa "nova espécie", o gene monstruoso. Não parece tarefa fácil conceber "violência mais nefasta sobre os afetos e as emoções que o horror uterino" 6 monstruoso em Seth, ou o aspecto mutacional, código caro à pós-modernidade, surge aqui numa representação carnal, extrema. E se é algo afeito à mesma pós-modernidade o individualismo exacerbado, fruto de um momento no qual códigos antes rígidos ou importantes - família, igreja, estado etc. - afrouxam ou desaparecem, raras metáforas tão radicais para o individualismo contemporâneo como a transformação de Seth em A mosca. Embora, naturalmente, Seth não buscasse diferenciação tão animalesca. Obtêm-na por um experimento malfadado, sem volta; passo a passo seu corpo sofre sua desfiguração, a besta vai ganhando terreno sobre o humano. Aqui, a mudança de identidade passa pela mudança biológica, e poderíamos ver no filme certa representação horrenda de um mundo onde nada é satisfatório, sempre queremos mais, ainda que às custas de nossa essência. Seth torna-se um super homem elétrico e de força descomunal; daí, torna-se a mais diferente das criaturas, produto mórbido da ciência e da ambição. É a metamorfose, o aspecto mutante, que interessa o cineasta. Antes, interessa-nos entender o personagem como um ser que carrega em si a potencialidade de assumir outra forma: o mutante, por assim dizer. Como um camaleão, o cientista racional e equilibrado perde es-

6 Nogueira, 2002, p. 52 
paço para o monstro irracional. Seth, agora com o DNA da mosca, logo se vai tornando a própria besta, criatura que "perde o dom da comunicação para agir apenas com violência"7, pois que a violência seria a forma de comunicação da animalidade. Assim, A mosca é uma explanação sobre as potencialidades de mutação de nossas identidades, ou de assunção ou não delas, ainda que explicitadas aqui de forma tão radical, até mesmo desagradável. O limite entre o homem e o animal, entre o civilizado e o bárbaro, tudo parece ruir, até a plena fusão. Baudrillard, em A transparência do mal, escreve:

De todas as próteses que balizam a história do corpo, o duplo é sem dúvida a mais antiga. Mas o duplo não é uma prótese: é uma figura imaginária que - tal como a alma, a sombra, a imagem no espelho - persegue o sujeito como seu outro, faz com que seja ao mesmo tempo ele mesmo e não se pareça nunca também, que o persegue como uma morte sutil e sempre conjurada. Nem sempre porém: quando o duplo se materializa, quando se torna visível, significa morte iminente. (BAUDRILLARD, 1990, p. 121)

Assim, o duplo surge em A mosca, Seth dá lugar ao monstro, uma besta íntima, inevitável, que surge e se apossa de seu ser, sua vida, remodelando sua identidade, aniquilando-a quando já às margens da plena animalidade. É uma pintura poderosa e dolorosa sobre a complexidade do ser, ao mesmo tempo sobre a inevitabilidade de certa tendência irracionalista imanente no homem. Para o ser que se pretende um mero civilizado, é uma obra abjeta, sórdida como o monstro que fotografa, pois traz a incômoda lembrança das nuances obscuras que os códigos da civilidade pretendem manter escondidas. Baudrillard (1990), ao tratar das próteses afeitas ao espírito contemporâneo, bem podia pensar em silicones, membros postiços, tinturas; simulacros para uma possível outra identidade, ou para a busca infinita de outra identidade, radicalmente atingida pelo homem monstro de $A$ mosca.

\subsection{Uma história de violência}

Em Marcas da violência, quase vinte anos depois, Cronenberg reviu, sem o mesmo horror imagético, alguns códigos presentes em A mosca. Desta vez, temos como protagonista o (aparentemente) pacato Tom Stall, dono de um café, vivendo numa modesta cidade no interior dos Estados Unidos, marido tranquilo e pai de uma pequena menina e um rapaz adolescente. Um incidente inesperado, no entanto, parece por uma pedra em sua vida plana e tranquila: após dois facínoras de passagem pela cidade entrarem na lanchonete de Tom e fazerem reféns, uma rápida e insólita mutação parece ocorrer em Tom. Em poucos segundos, desarma um dos bandidos, e com disparos rápidos e certeiros dá fim a ambos. Aparentemente, um ato isolado de heroísmo, transmiti7 Nogueira, 2002, p. 54 
do por todo o país pela televisão. Pouco tempo depois, gângsteres começam a aparecer na cidade e sondar Tom, mas chamando-o por outro nome: Joey Cusack. Tom permanece impassível, como se não os conhecesse. Os bandidos começam a cercar a vida de Tom e sua família com ameaças, e num diálogo importante o líder deles (vivido por Ed Harris) pergunta à esposa de Tom (Maria Bello): "por que você acha que seu marido é tão bom em matar"? Sua afirmação é: Tom fora um assassino profissional, e deve agora voltar à sua cidade Filadélfia - para rever seu irmão Ritchie (William Hurt), um poderoso mafioso. Quando, em momento de clímax, o filho adolescente de Tom surge raptado pelos bandidos armados, o pai reage de maneira assombrosa e inesperada enfrenta-os, um deles assassina manualmente, com destreza profissional, o segundo com disparos certeiros e é ferido pelo terceiro, que será morto pelo filho. Novamente um pacato Tom Stall cede lugar a um violento Joey Cusack.

Ainda que pareça um tema batido - o passado secreto que ressurge e deve ser enfrentado ou eliminado - Cronenberg o explora de forma singular. Tom deixa de ser Tom quando as circunstâncias violentas o exigem - e volta a ser Joey, um assassino de aluguel que fugiu da quadrilha de seu irmão Ritchie, passou anos "aprendendo" a ser Tom, casou, teve filhos, mas mantém em si ainda o embrião da violência que adquiriu ao longo de uma vida. Após o incidente com mais mortes, sua situação perde sustentação. O pai deixa de ser pai e perde o respeito do filho. A esposa o vê como um falso. Para este Tom-Joey, a vida surge como num ponto de inflexão que exige a escolha de um caminho; e impõe-se prontamente uma questão: qual será de fato sua identidade? um ser violento capaz de maquiar e esconder seus impulsos a fim de viver uma "vida normal"? ou um ser que, tendo o passado violento, consegue "vestir a máscara" de um personagem tranquilo, generoso, bom pai de família? Giddens afirma, ao comentar o processo de reflexão sobre o "eu":

No projeto reflexivo do eu, a narrativa da auto-identidade é inerentemente frágil. A tarefa de forjar uma identidade distinta pode ser capaz de trazer ganhos psicológicos específicos, mas também é claramente um peso. Uma auto-identidade precisa ser criada e de certa forma reordenada contra o pano de fundo das experiências cambiantes da vida diária e das tendências fragmentadoras das instituições modernas. Ademais, a sustentação de uma tal narrativa afeta diretamente, e ate certo ponto ajuda a construir, tanto o corpo quanto o eu. (GIDDENS, 2002, p. 172)

Assim, Tom tem sua "identidade cambiante" colocada à prova no caos da situação inesperada em que vive. Aqui, o descompasso da vida e suas provas serão o fator a desencadear as crises identitárias em Tom. Algo de genético em Marcas da Violência parece ser evocado, como que em A mosca; podemos comparar dois momentos, uma cena de sexo entre Tom e a esposa no começo do filme, afetuosa, e outra após os desentendimentos, no qual Tom se transmuta em Joey, violenta. A Tom restaria matar a larva de Joey que permanece nele, 
que julgara estar morta e a crueza da vida fez emergir. É evidente que, aos nos referirmos a certo "aspecto genético", não limitamos a noção de identidade a uma causalidade biológica. As relações que aproximam A mosca de Marcas da violência são a sugestão de que habitamos em nós mais de um "eu", o qual pode expressar-se de forma violenta, monstruosa, pacífica. Cuche (1999), ao refletir sobre identidade e cultura, reafirma uma posição por muitos defendida, a identidade enquanto produto social.

Se a identidade é uma construção social e não um dado, se ela é do âmbito da representação, isto não significa que ela seja uma ilusão que dependeria da subjetividade dos agentes sociais. A construção da identidade se faz no interior dos contextos sociais que determinam a posição dos agentes e por isso mesmo orientam suas representações e suas escolhas. Além disso, a construção da identidade não é uma ilusão, pois é dotada de eficácia social, produzindo efeitos sociais reais. (CUCHE, 1999, p. 182)

Assim, Tom, ou Joey, é um ser que veste máscaras em resposta aos estímulos violentos de mundos antagônicos: o passado violento e o presente tranquilo. A desarmonia criada pelo choque destes mundos leva Tom-Joey a sua crise pessoal. Afinal, ele retorna à cidade de origem, vai ao encontro do irmão, sereno, impassível, desarmado. Após dominar e exterminar toda a gangue de seu irmão Ritchie, com uma habilidade assassina que emerge abruptamente, não hesita em liquidar o próprio irmão - como se, ao matá-lo, estivesse expurgando qualquer herança da violência, contida simbolicamente em seu irmão (que representa seu passado e sua criação enquanto um assassino) e resgatando para si o sossego de outrora. Enfim abdica de uma máscara incômoda que vestira por anos e agora Ihe voltara como um pesadelo. Ao retornar da Filadélfia, é aceito pela sua família de volta, como o que fora até então: pai de família, homem pacato, trabalhador tranquilo.

\section{M. BUTTERFLY: UMA NOVA IDENTIDADE NO JOGO DE MÁSCARAS DO AMOR}

Produção dramática que remete à peça teatral de mesmo nome do escritor David Henry Hwang, M. Butterfly remonta a Pequim dos anos 60 para contar a história de um diplomata francês, René Gallimard, em serviço na embaixada da França em território chinês, onde vivencia o grande amor de sua vida com a bela Song Liling, a "Madame Butterfly", levando-o a uma transmutação total em sua personalidade. A película é baseada na história real do diplomata francês Bernard Boursicot e do cantor de ópera de Pequim Shi Pei Pu, ambos acusados e condenados pelo governo francês por espionagem.

O filme de David Cronenberg começa com uma recepção na embaixada 
francesa, em Pequim, onde Gallimard assiste à apresentação da peça Madame Butterfly, sendo ele apresentado, em seguida, à sua protagonista, a cantora de ópera Song Liling, por quem se apaixona perdidamente e com quem vivencia, às avessas, a história contada no espetáculo homônimo. O que o diplomata francês desconhece é que a bela Song é uma "espiã" do governo chinês instruída a conquistar sua confiança e seu amor para transformá-lo em um agente duplo. A cantora de ópera o envolve em uma atmosfera sublime de recato e submissão, solicitando sua complacência com os costumes orientais sob os quais ela foi criada, de tal forma que René cede completamente aos seus encantos, mantendo com ela um relacionamento baseado em paixão, obsessão e ingenuidade.

Ao analisar a violência nos filmes de Cronenberg, Nogueira (2002, p. 80) discorre que o enamoramento do diplomata francês encontra na resistência de Butterfly o reforço a sua inestimável atração, baseada no jogo de proibições, privações e prêmios, regulado pelo confronto dos códigos culturais que os separam - a modernidade da cultura e conduta ocidentais em conflito com o comedimento ancestral daquela diva. A distância interposta entre os amantes funciona como um campo magnético à paixão reverenciada, sem reservas e cada vez mais obsessiva de Gallimard pelo amor proibido e socialmente condicionado da cantora de ópera.

Uma mulher recatada, segundo a rígida moral chinesa, Song consegue se relacionar com Gallimard, em todas as ocasiões, totalmente vestida e, quando a farsa é ameaçada, ela se livra da "saia justa", sob a alegação de que está grávida, recebendo todo o apoio do amante para dar luz ao rebento. Butterfly retorna com a criança, que é imediatamente retirada de ambos, sendo ela presa e ele chantageado pelo governo chinês a fim de transmitir informações confidenciais sobre o governo francês. Temeroso pela segurança de Song e do filho, René torna-se, então, um agente duplo, o que já começa a lhe desencadear a divisão de sua personalidade, ainda que, neste momento, apenas no âmbito de suas relações político-sociais.

Em meio à revolução cultural, a situação política na China se complica e o diplomata retorna ao seu país de origem, onde apresenta um comportamento que denota sinais evidentes e mais profundos de mudança em sua personalidade, o que evidencia uma crise de identidade. Segundo a concepção objetivista de identidade cultural, citada por Denys Cuche (1999), a identidade é preexistente no indivíduo e moldada por seu grupo cultural de origem.

O indivíduo, devido a sua hereditariedade biológica, nasce com os elementos constitutivos da identidade étnica e cultural, entre os quais os caracteres fenotípicos e as qualidades psicológicas que dependem da "mentalidade", do "gênio" próprio do povo ao qual ele pertence. (...) A identidade é vista como uma condição imanente do indivíduo, definindo-o de maneira estável e definitiva. (CUCHE, 1999, p. 178-179) 
Desta forma, a identidade etnocultural, por ser a primeira, estabelece os vínculos mais determinantes de um indivíduo, tendo em vista que, em seu grupo étnico, são partilhadas suas emoções e solidariedades basilares. Portanto, esta é a identidade que Gallimard passa a ter afetada ao chegar em Paris, dando vazão a uma identidade cultural subjetivista, que considera seu caráter variável e efêmero. Por meio dela, o sentimento de vinculação ou pertencimento a uma coletividade imaginária prepondera na representação que ele faz de sua realidade social circundante. Isso faz com que ele escolha a identidade que queria para si, o que pode ser notado pelo lugar onde ele vai morar, tomado por adereços orientais, numa tentativa exaustiva de recriar um ambiente ilusório diante da inevitável violência da solidão. Além disso, seus hábitos alimentares e a vida que passa a levar demonstram claramente a influência da cultura do Oriente em seu cotidiano.

Uma série de acontecimentos políticos permeia a narrativa e, em meio à imersão na qual René se encontrava, Song reaparece em sua casa, passando a coabitar com ele em território francês. Sob a ameaça de que nunca mais o casal teria acesso ao filho, Gallimard continua a exercer o papel de agente duplo, passando informações privilegiadas do governo francês ao chinês.

O diplomata parece estar completamente enfeitiçado por Song, a ponto de ignorar, o tempo todo, que a tradicional ópera chinesa é encenada apenas por atores, o que enseja dizer que sua amante era, na verdade, um homem. A magia decorrente do envolvimento afetivo proibido permeado pelo distanciamento cultural, envolto numa redoma de recato, censura e sutileza interposta entre os amantes, funciona como um campo magnético arrebatador e devoto que aliena e transcende toda e qualquer razão.

Desconfiado das atitudes de Gallimard, o governo francês o flagra interceptando correspondências sigilosas da França para enviá-las ao governo chinês e o leva a julgamento por traição. Em audiência, René descobre que Song é um homem, sendo exposto publicamente a uma situação vexatória. Uma confusão toma conta de seus sentimentos quando ambos são transportados juntos à prisão, após a condenação. O homem que o francês desconhece se despe de suas vestes masculinas, fazendo esvair-se, em seu íntimo, a divinização da mulher que não havia passado de uma vergonhosa e intolerável fraude. Fragilizado pública e moralmente, eclode em seu ser a dor, decorrente da perturbação e desordem daquela paixão, sempre movida por um jogo oportunista de aproximações e renúncia, obsessão, possessão erótica, segredo, submissões, trocas, vulnerabilidades e carências.

Diante do sofrimento imposto pela desilusão e perda insuportável, que se torna insuperável, o desejo pela morte do ser amado se confunde com o desejo por sua própria morte, já que a humilhação que lhe foi imposta tornou sua vida desprovida de valor, sem nenhum resquício de dignidade, irrecuperável. Nesta angustiante confusão geral, o homem ultrapassa o limite da razão, transformando-se em seu objeto de desejo, através de um doloroso processo de mutação 
que transcende as barreiras do compreensível. Durante o cumprimento de sua pena, Gallimard assume a identidade e representação de Butterfly, mulher que morre por causa de um amor ilusório, encontrando o seu trágico final ${ }^{8}$.

Ao se transvestir de personagem, o amante desolado integra as referências que se identificam com sua história, conforme explana Cuche (1999, p. 194-195), ao mesmo tempo em que demonstra uma atitude transexual, afinal, Baudrillard (1990) explica que "o transexual tem por objetivo o artifício, seja ele o de mudar de sexo ou o jogo dos signos vestimentares, morfológicos, gestuais, característicos dos travestis" 9 . Gallimard vivencia uma verdadeira reviravolta em seu ser, uma vez que ele passa por momentos de indeterminação, angústia e confusão, adentrando num processo de imersão radical, no qual se percebe enorme identificação de seu estado de espírito com a peça teatral, uma indelével analogia.

A ficção é uma necessidade cotidiana. Cada um, para existir, conta-se uma história. É o que nos ensina a observação empírica, é o que ressaltam também abordagens eruditas, tais como as das histórias de vida ou da etnometodologia. Em cada um desses casos, vê-se bem que o eu só é uma frágil construção, ele não tem substância própria, mas se produz através das situações e das experiências que o moldam num perpétuo jogo de esconde-esconde. A imagem é talvez um pouco forte, mas será que não ilustra as múltiplas mudanças que constituem um mesmo indivíduo? Por um lado, no decorrer de uma mesma existência, cada um muda diversas vezes. (MAFFESOLI, 1996, p. 303-304)

Partindo da fragilização do "eu” perceptível na literatura, Maffesoli (1996) sustenta que o indivíduo vivencia o "romance da vida corrente", sendo o "eu" apenas uma ilusão, desprovido de unidade em suas diversas representações. Filosoficamente, o sujeito é complexo e composto pela multiplicidade de interferências recebidas ao longo da existência.

Assim, Gallimard se perde e se encontra em sua própria história com Butterfly. Em meio às suas inquietações, não vê outra saída senão se entregar à tragédia de sua sina, cujo desenlace é violento. O suicídio representa uma morte dupla, do amante e da amada, confundidos no mesmo corpo. O sacrifício final é a solução irrecusável, a única viável ao sujeito perdido na densidade de sentimentos confusos, manipulados, expostos e incompreendidos.

8 Na ópera de Giacomo Puccini, baseada no drama de David Belasco, Butterfly se mata por um amor total ao empunhar uma faca no ventre. No filme de Cronenberg, a arma do crime é um caco do espelho que René usa para se maquiar e se transformar em M. Butterfly, cortando o próprio pescoço após encenar a personagem num misto de espetáculo catártico e cerimônia fúnebre na prisão.

9 Baudrillard, 1990, p. 27. 


\section{CONSIDERAÇÕES}

É certo que o resistente fascínio pela obra de David Cronenberg é devido a suas opções estéticas e temáticas, no mais das vezes, altamente corajosas, invulgares, polêmicas. Daí também advém certa pecha de "maldito", ou de um autor renegado a públicos restritos. No entanto, é marca de sua filmografia a preocupação com problemas contemporâneos; e de certa forma, talvez Cronenberg atue tal qual o antropólogo, na medida em que frequentemente direciona seus esforços a fim de entender o homem em sua complexidade, seu comportamento, sua alma, suas loucuras. Se em A mosca já prevê o ser como algo mutante, não apenas na aparência mas em seu íntimo, em Marcas da violência mostra a necessidade desesperada do homem de buscas máscaras distintas conforme o andamento ardiloso do mundo - a identidade assumida como forma de resistência a poderes maiores que nós. Em M. Butterfly, ocorre a discussão acerca da identidade na figura travestida, e também no processo pelo qual passa o protagonista, de dedicado amante para melancólico suicida.

Seria possível dedicar um sem número de páginas para tratar dos problemas identitários na obra de Cronenberg. Seus filmes, munidos de relativa homogeneidade temática, sempre a buscar objetos perdidos nos confins da alma humana, servem como reflexão fundamental sobre o comportamento do homem no contexto pós moderno. Filmes como Gêmeos, Spider, Senhores do crime ou Crash o atestam, bem como as obras lembradas neste pequeno trabalho.

\section{REFERÊNCIAS}

BAUDRILLARD, Jean. A transparência do mal: ensaio sobre os fenômenos extremos. Campinas: Papirus, 1990.

CUCHE, Denys. A noção de cultura em ciências sociais. Bauru: EDUSC, 1999.

GIDDENS, Anthony. Modernidade e identidade. Rio de Janeiro: Jorge Zahar, 2002.

MAFFESOLI, Michel. No fundo das aparências. Petrópolis: Vozes, 1996.

NOGUEIRA, Luís. Violência e cinema: monstros, soberanos, ícones e medos. Covilhã:

Universidade da Beira Interior, 2002.

Filmografia

A mosca (The fly, 1986), direção de David Cronenberg.

M. Butterfly (idem, 1993), direção de David Cronenberg.

MARCAS da violência (A history of violence, 2005), direção de David Cronenberg. 


\section{André de Paula Eduardo}

Mestrando no Programa de Pós-Graduação da Universidade Estadual Paulista - Unesp (campus de Bauru); Graduado em Comunicação Social - Jornalismo pela mesma instituição; desenvolve projeto com ênfase no romance-reportagem brasileiro dos anos 70, as marcas entre ficção e o factual e o trânsito entre jornalismo, literatura e cinema no período.

\section{Deborah Cunha Teodoro}

Desenvolve projeto sobre políticas públicas voltadas para o setor de radiodifusão, com ênfase em conceitos como cidadania e democracia. Graduada em Comunicação Social (Jornalismo) pela Universidade Estadual Paulista - Unesp (campus de Bauru) e em Direito pela ITE - Instituição Toledo de Ensino de Bauru; mestranda no Programa de Pós Graduação da Unesp. 